\title{
Role of Hearth Program with Undernutrition Incidence among Toddlers in Tangerang City
}

\author{
Peranan Program Pos Gizi dengan Kejadian Gizi Kurang pada Anak \\ Bawah Lima Tahun di Kota Tangerang
}

\author{
Gizella*, Dany Hilmanto**, Dedi Rachmadi***
}

\begin{abstract}
*Midwifery Master Program, Faculty of Medicine, Padjajaran University, Bandung, Indonesia, ** Child Health Studies Department, Faculty of Medicine, Padjajaran University, Bandung, Indonesia
\end{abstract}

\begin{abstract}
Abtract
Toddler is a group at risk of undernutrition in which World Health Organization stated that toddler mortality because of undernutrition was $54 \%$ in 2002 . In Indonesia, its prevalence increased from $17.9 \%$ in 2010 to 19.6\% in 2013. In Tangerang City, there was 1.43\% of toddlers suffering from undernutrition in 2013. This study aimed to prove in valid the relation between Hearth Program, which covered behaviors of food providing, toddler's hygiene, health care seeking and toddler parenting, with undernutrition incidence among toddlers. This study was quantitative, cross-sectional, using primary data, analyzed in univariate, bivariate and multivariate within September 2015. Samples were taken by total sampling as many as 60 toddlers suffering from undernutrition in Tangerang City. Results showed that 12 (20\%) of 60 toddlers suffered from very underweight nutrition and the remaining 48 toddlers (80\%) suffered from underweight nutrition. There was a relation between food-providing behavior and health-care seeking behavior with undernutrition among toddlers. Variable food-providing behavior was the dominant factor influencing undernutrition among toddlers with $\mathrm{OR}=4.655(\mathrm{Cl}=1.052-20.6)$ after controlled by the variable health care-seeking behavior.
\end{abstract}

Keywords: Hearth program, toddlers, undernutrition

\begin{abstract}
Abstrak
Kelompok yang rentan terhadap gizi kurang adalah anak bawah lima tahun (balita). World Health Organization menyatakan kematian balita akibat gizi kurang sebesar 54\% pada tahun 2002. Di Indonesia, prevalensinya mengalami peningkatan dari 17,9\% tahun 2010 menjadi 19,6\% tahun 2013. Di Kota Tangerang, terdapat 1,43\% balita yang mengalami gizi buruk tahun 2013. Penelitian ini bertujuan untuk membuktikan secara valid hubungan Program Pos Gizi yang meliputi perilaku pemberian makan, kebersihan balita, pencarian pelayanan kesehatan dan pengasuhan balita dengan kejadian gizi kurang pada balita. Penelitian ini merupakan penelitian kuantitatif, potong lintang, menggunakan data primer serta dianalisis secara univariat, bivariat, dan multivariat selama bulan September 2015. Sampel diambil secara total sampling sebanyak 60 balita yang mengalami gizi kurang di Kota Tangerang. Hasil menunjukkan bahwa dari 60 balita yang mengalami gizi kurang, sebanyak 12 balita (20\%) mengalami gizi sangat kurus dan sisanya sejumlah 48 balita (80\%) mengalami gizi kurus. Terdapat hubungan perilaku pemberian makan dan pencarian pelayanan kesehatan dengan gizi kurang pada balita. Variabel perilaku pemberian makan merupakan faktor dominan yang memengaruhi gizi kurang pada balita dengan $\mathrm{OR}=4,655(\mathrm{Cl}=1,052-20,6)$ setelah dikontrol oleh variabel perilaku mencari pelayanan kesehatan.
\end{abstract}

Kata kunci: Program pos gizi, anak bawah lima tahun, gizi kurang

How to Cite: Gizella, Hilmanto D, Rachmadi D. Role of hearth program with undernutrition incidence among toddlers in Tangerang City. Kesmas: National Public Health Journal. 2016; 11 (1): 14-19. (doi:10.21109/kesmas.v11i1.757)
Correspondence: Gizella, Midwifery Master Program Faculty of Medicine Padjajaran University, Eijkman Street No.38 Bandung 40161, Indonesia, Phone: -, email: gizella.nabila@gmail.com

Received: March $1^{\text {st }} 2016$

Revised: April 26 $6^{\text {th }} 2016$

Accepted: August $11^{\text {th }} 2016$ 


\section{Introduction}

Almost all countries have "nutrition problems" and perform many actions to conquer nutrition problems in the world including Indonesia. However, the actions are not yet completely succeed. Now people are facing multiple nutrition problems, namely undernutrition and overnutrition. ${ }^{1}$

One of groups at risk of nutrition problem is toddler group because toddler period is a transition period in term of food consumption from infant's food to adult's food. Therefore, this is very influenced by family role because food received by toddlers depend on their family's affordability. Families that have good knowledge and awareness related to family nutrition will be able to prepare nutritious food for their toddlers. Determination of nutritional status can be conducted by weighing body weight and measuring body height of toddlers compared to age toward World Health Organization/National Center for Health Statistic (WHO/NCHS) $(<-3 \mathrm{SD}$ WHO-NCHS). ${ }^{1}$

In Fatma's study, there were three indicators of family awared of nutrition which was well performed by mothers of toddlers, except exclusive breastfeeding and consumption of various food. Meanwhile, exclusive breastfeeding and consumption of various food are necessary to meet toddler's need of balanced nutrition. ${ }^{1}$ Thus, undernutrition and malnutrition problems among toddlers remain the main nutrition problems that need to be concerned on. According to WHO, infant and toddler mortality because of undernutrition and malnutrition was $54 \%$ in $2002 .^{2}$

Negative impacts of nutrition problems among toddlers include brain and intelligence development disorder, physical growth and body metabolism disorders as well as the decrease of cognitive ability and learning achievements. Study conducted by Hartanto with Kodim, ${ }^{3}$ found relation between condition of toddlers' nutritional status and their learning achievements in which the low numerical learning achievements could occur among children with undernutrition at the time of infant age, meanwhile verbal learning achievement was influenced by nutritional status along their lifetime. Moreover, another effect of nutrition problem is the decrease of body immune, so children easily get ill and have a high risk of suffering from degenerative diseases at old ages, which apparently will decrease Indonesian human resources, productivity and competitiveness.

According to WHO in 2010, public health problem is considered serious if the prevalence of malnutrition less than between $20-29 \%$, while the prevalence is considered very high if $\geq 30 \%$. Basic Health Research data in 2007 showed the prevalence of malnutrition in Indonesia was $18.4 \%$ and $17.9 \%$ in 2010, then increased in 2012 that was $19.6 \%$ consisting of $5.7 \%$ malnutrition and
13.9\% undernutrition. Thus, malnutrition and undernutrition in Indonesia remain the public health problems closer to the high prevalence. ${ }^{4}$

In Tangerang City, there were malnutrition records in 2008 by $1.54 \%, 1.89 \%$ in $2009,1.91 \%$ in $2010,1.75 \%$ in 2011 and $1.43 \%$ in 2013. Based on the data, there was an increase from 2008 to 2010 . For undernutrition data, there was a decrease by $0.3 \%$. In 2012, toddlers with malnutrition were mostly found in Benda Subdistrict by $3.27 \% .^{5}$

Undernutrition among toddlers is influenced by many factors. Based on a study, there were several factors influencing to undernutrition incidence among toddlers including maternal education level, child's birth weight, birth intervals and chronic infections. ${ }^{6}$ In another study, the factors which also influence to toddler's nutritional status is baby weighing and conscious family nutrition status. ${ }^{7}$ Furthermore, baby parenting is also the factor that has significant influence to undernutrition incidence among toddlers both in urban and rural areas. ${ }^{8}$

Considering the cause of undernutrition incidence among toddlers is complex, therefore, handling actions need integrated approach from many aspects of children's life. This means that it is not enough by improving food aspect only, but also children's living environment, such as parenting patterns, education and environmental health, quality of health services, etc. The government planned seven major activities in order to prevent and handle malnutrition within 2005 - 2009. Those seven major activities included revitalization of integrated health care, revitalization of primary health care, health and nutrition intervention, promotion of conscious family nutrition, family empowerment, advocacy and assistance as well as revitalization of food and nutrition vigilance system. One of nutrition recovery activities among people, especially toddlers with people empowerment approach, is Hearth Program. ${ }^{9}$

Hearth Program is family-based nutrition program. The principle of such program is that poverty is not the main cause of undernutrition because there are some poor families whose children are healthy (good nutrition) found due to implementation of good parenting patterns. Undernutrition is commonly caused by food-providing practice or inproper parenting patterns. By Hearth Program, hopefully undernutrition can be conquered with behavioral change. During Hearth Program activities, parents learn positive behavior together and implement it at home. Tangerang City Government has performed actions to handle undernutrition among toddlers that cover balanced nutrition promotion including nutrition counseling at integrated health care, provision of additional food including Complementary Feeding and Nutrition Clinic. However, as a matter of fact, there were still many families that had unhealthy nutritional beha- 
vior.

Therefore, this study aimed to prove in valid any relation between Hearth Program consisting of food-providing, toddler's hygiene, health care seeking and toddler parenting behaviors with undernutrition incidence among toddlers in Tangerang City.

\section{Method}

This study was quantitative study with observational design and cross-sectional approach of time. Variable that would be observed consisted of dependent variables including undernutrition with categories of toddlers with underweight nutrition and very underweight nutrition. Category toddlers with very underweight nutrition was nutritional condition of toddlers measured anthropometrically based on body weight index in accordance with body height with $\mathrm{Z}$ score $<-3$. Meanwhile, the category underweight if $Z$ score SD -3 SD to $<-2$ SD. Then independent variable was Positive Deviance/Hearth Program consisting of variables food-providing, toddler's hygiene, health care seeking and toddler-parenting behaviors. This study used primary data as taken on September 2015 at six places for Hearth Program in Tangerang City (Tanah Tinggi Subdistrict, Larangan Indah Subdistrict, Karang Mulya Subdistrict, North Poris Plawad Subdistrict, Karang Anyar Subdistrict and Sukajadi Subdistrict). Toddlers participated at Hearth Program activities for one month. Samples of study as taken by total sampling were 60 toddlers. Data were obtained from each primary health care with inclusion criteria including mothers who had toddlers with underweight and very underweight nutrition aged of $12-59$ months that were at six places for Hearth Program and following Hearth Program activities regularly within 15 days.

Hearth Program was executed for one month as conducted by Tangerang City Health Agency and six primary health care as Hearth Program targets with the details were 15 days in Hearth class and the next 15 days practicing at home, then followed by home visits on the $18^{\text {th }}$ and $30^{\text {th }}$ day. Hearth Program activities performed by mothers of toddlers were food-providing, parenting, tod- dler's hygiene behaviors and such activities were directly practiced in Hearth Program places and implemented at home.

By using the strength of test $90 \%$ and $95 \%$ confidence interval $(\mathrm{CI})$, data was analyzed in univariate, bivariate and multivariate. Bivariate analysis used chi square test and multivariate analysis used multiple logistic regression with prediction model.

\section{Results}

Table 1 showed that based on results of bivariate analysis using chi square test with alpha $5 \%$ and $95 \% \mathrm{CI}$, there was a significant relation between behavior of food provision and undernutrition among toddlers ( $\mathrm{p}$ value $=$ 0.022 ; odds ratio $(\mathrm{OR})=6.0 ; 95 \% \mathrm{CI}=1.42-25.27$ ), likewise a significant relation was found between health care-seeking behavior and undernutrition among toddlers $(\mathrm{p}$ value $=0.038 ; \mathrm{OR}=4.9 ; 95 \% \mathrm{CI}=1.26-18.77)$.

Then results of analysis on relation between behavior of toddler's hygiene and undernutrition among toddlers showed no significant relation found $(\mathrm{p}$ value $=1.000$; $\mathrm{OR}=1.0 ; 95 \% \mathrm{CI}=0.28-3.60$ ), also no significant relation found between parenting behavior and undernutrition among toddlers $(\mathrm{p}$ value $=0.746 ; \mathrm{OR}=0.7$; $95 \% \mathrm{CI}=0.18-2.65)$.

Multivariate analysis was started by selection of candidate variables that was conducting bivariate analysis using simple logistic regression between dependent variable and independent variable. If there was $p$ value < 0.25 , thus such variable could include into multivariable model. According to the candidate selection using simple logistic regression, variables included into multivariate analysis were food-providing behavior $(\mathrm{p}$ value $=0.022$ ) and health care-seeking behavior $(\mathrm{p}$ value $=0.038$ ) Meanwhile, variable toddler's hygiene behavior and toddler parenting behavior had $\mathrm{p}$ value $>0.25$ (1.000 and 0.746 ), so both did not include into multivariate analysis.

Table 2 showed the final model of multivariate analysis in which the most dominant variable that had influence to undernutrition incidence among toddlers was variable food-providing behavior with $\mathrm{OR}=4.655$,

Table 1. Bivariate Analysis

\begin{tabular}{|c|c|c|c|c|c|c|c|c|c|}
\hline \multirow{3}{*}{ Variable } & \multirow{3}{*}{ Category } & \multicolumn{4}{|c|}{ Underweight among Toddler } & & & \multirow{3}{*}{ OR $(95 \% \mathbf{C I})$} & \multirow{3}{*}{ p Value } \\
\hline & & \multicolumn{2}{|c|}{ Very Underweight } & \multicolumn{2}{|c|}{ Underweight } & \multicolumn{2}{|c|}{ Total } & & \\
\hline & & $\mathbf{N}$ & $\%$ & $\mathbf{N}$ & $\%$ & $\mathbf{N}$ & $\%$ & & \\
\hline \multirow[t]{2}{*}{ Food-providing behavior } & Bad & 9 & 36 & 16 & 64.0 & 25 & 100 & 6.0 & 0.022 \\
\hline & Good & 3 & 8,6 & 32 & 91.4 & 35 & 100 & $(1.42-25.27)$ & \\
\hline \multirow[t]{2}{*}{ Toddler's hygiene behavior } & $\mathrm{Bad}$ & 5 & 20 & 20 & 80.0 & 25 & 100 & 1,0 & \\
\hline & Good & 7 & 20 & 28 & 80.0 & 35 & 100 & $(0.27-3.60)$ & 1.000 \\
\hline \multirow[t]{2}{*}{ Health care-seeking behavior } & $\mathrm{Bad}$ & 8 & 36.4 & 14 & 63.6 & 22 & 100 & 4.9 & \\
\hline & Good & 4 & 10.5 & 34 & 89.5 & 38 & 100 & $(1.26-18.77)$ & 0.038 \\
\hline \multirow[t]{2}{*}{ Toddler-parenting behavior } & Bad & 4 & 16.7 & 20 & 83.3 & 24 & 100 & 0.7 & \\
\hline & Good & 8 & 22.2 & 28 & 77.8 & 36 & 100 & $(0.18-2.65)$ & 0.746 \\
\hline
\end{tabular}


Table 2. Final Model of Multivariable Analysis

\begin{tabular}{lccccc}
\hline Variable & OR & SE & $\mathbf{p ~ V a l u e ~}$ & & \multicolumn{2}{l}{$\mathbf{9 5 \% \text { CI for EXP (B) }}$} \\
\cline { 5 - 6 } & & & & Lower & Upper \\
\hline Food-providing behavior & 4.655 & 0.759 & 0.043 & 1.052 & 20.609 \\
Health care-seeking behavior & 3.605 & 0.724 & 0.077 & 0.872 & 14.907 \\
\hline
\end{tabular}

which means that group of toddlers raised by mothers having bad behavior in providing food had 4.655 times higher risk of suffering from very underweight nutrition than toddlers raised by mothers who had good behavior after controlled by variable health care-seeking behavior.

\section{Discussion}

Every parent definitely wanted their children to grow healthy and smart. To embody it, every child must get attention, control and treatment thoroughly, especially in terms of their growth and development. Even though development of children occurred naturally, but such a process really depended on parents, especially mothers as the parent in providing parenting pattern to toddlers. Moreover, period of five years old (toddler period) is the important period within child development and the period determining their physical, psychic and intelligence development. ${ }^{10}$

WHO stated that the major problem in the field of health is malnutrition, specifically in developing countries, and Indonesia is one of the countries as Basic Health Research data in 2013 showed malnutrition prevalence reached $19.6 \%$ that consisted of malnutrition $(5.7 \%)$ and undernutrition $(13.9 \%)$. Study conducted by Kartono, et al, 11 concerning condition of toddler nutrition in three regions during economic crisis including Bogor, Tangerang and Bekasi in 1996 and 1999 showed that amount of toddlers with undernutrition and malnutrition was almost half of the amount of toddlers with good nutrition. Likewise the results of this study showed two of ten toddlers suffering from undernutrition were toddlers with very underweight nutrition.

There were many actions performed by the government to decrease undernutrition incidence, one of those actions was through Hearth Program consisting of foodproviding behavior, toddler's hygiene behavior, health care-seeking behavior and toddler-parenting behavior. Based on results of this study, there were still many bad practices of food-providing, toddler's hygiene maintanance, health care-seeking and toddler-parenting in six subdistricts as Hearth Program targets. This case could be one of causes why toddlers with undernutrition incidence was still found in six subdistricts around Tangerang City. Therefore, eating habit in household was important to be concerned on because the eating habit influenced the selection and the use of food, then influ- enced high or low household's food quality.

Execution of Hearth Program activities was only one month and as the target, such program activities were only conducted in six subdistricts around Tangerang City with each of the program place only took 10 samples based on criteria, so there was a possibility of not significant variable finding in results of this study.

Results of study also showed relation between foodproviding behavior with undernutrition among toddlers whereby toddlers who got bad food providing behavior had six times higher risk of suffering from very underweight nutrition than toddlers who got the good behavior. Then the risk became 4.6 times after controlled by variable health care-seeking behavior. Likewise study conducted by Lubis, 12 that also showed any relation between food-providing behavior with toddler's nutritional status. Results of another study showed relation between parenting patterns toward nutritional status after following Hearth Program in any countries, such as in Guatemala dan Costa Rica, some mothers had good technique regarding food-providing, treatment for children while sick and recovery period. ${ }^{13}$

Bad behavior in providing parenting patterns to toddlers was related to knowledge, attitude or behavior of mothers, socio-cultural background that became factors in selecting inproper food. Because of food ingredient selection, the availability of adequate amount of food and food diversity were influenced by level of maternal knowledge about food and its nutrition. Ignorance of mothers could cause mistake in food selection, especially for toddlers. One of which was the needs of food/nutrition necessary to be prepared since prenatal period as mothers needed to manage their diet during pregnancy, then exclusive breastfeeding at period of 0 to 6 months as a study stating that exclusive breastfeeding was the controller to undernutrition incidence. ${ }^{14}$ The postponed breastfeeding initiative, not providing colostrum and inproper weaning were the risk factors significant for undernutrition among toddlers. Moreover, the optimum food-providing practice could improve children's nutritional status. ${ }^{15}$

Theoritically, self-hygiene was the important factor because of environment related to agents causing diseases, such as diarrhea, dengue hemorrhagic fever and infectious diseases in correlation with children's nutritional status. Child parenting from individual hygiene as- 
pect, environmental health and child safety regarding mothers' ability to maintain their children stay healthy and hygienic, children got healthy environment and avoided from injuries or accidents. However, this was not in line with results of this study that showed no any significant relation between toddler's hygiene behavior and undernutrition incidence.

There was a relation between health care-seeking behavior and undernutrition among toddlers whereby toddlers raised by families who had bad health care-seeking behavior had 4.9 times higher risk of suffering from very underweight nutrition than toddlers raised by families who had the good behavior. It was because toddler period is a period easily infected by diseases. Therefore, it took family's commitment, specifically mothers to carry their children to health care facilities if the children suffered from infectious diseases. Beside providing complete immunization to children before the age of one year, medical treatment of diseases during child period and getting professional's assistance on the right time played a role in maintaining children's health. Moreover, providing nutritional counseling for parents and good communication with mothers of toddlers would make nutritional status of toddlers better. ${ }^{16}$

Study conducted by Hidayat and Jahari, ${ }^{17}$ showed a significant difference that behavior of mothers who used health care facilities got more toddlers with good nutrition compared to mothers who did not use health care facilities.

Theoritically, parenting pattern to children is the important matter because it will influence their growth and development process. Child-parenting pattern is the ability of family and society to make time, give attention and supports in order to make children able to grow and develop as well as possible both physical, mental and social in form of attitude and behavior of mother or other sitters in terms of their closeness with children, providing food, maintaining hygiene and showing affection. Therefore, parenting is the factor closely related to growth and development of toddlers. Likewise the study conducted by Huriah, et $a l, 8$ that also found a relation between child parenting and nutritional status. However, this was not in line with results of this study showing no significant relation between toddler-parenting behavior with undernutrition incidence among toddlers.

\section{Conclusion}

Two of ten toddlers suffering from undernutrition are toddlers with very underweight nutrition. Mothers participate at Hearth Program within 15 days in Hearth Program places and 15 days at home following home visits. There is a significant relation between food-providing behavior and health care-seeking behavior and undernutrition among toddlers. There is no relation bet- ween toddler's hygiene behavior and toddler-parenting behavior with undernutrition among toddlers. Food-providing behavior is the dominant factor influencing undernutrition incidence among toddlers with variable health care seeking behavior as confounder.

\section{Recommendation}

It is necessary for every family to have good behaviors in terms of food-providing and health care seeking for their toddlers. It is hoped that Hearth Program as an action to improve food-providing and health care-seeking can be continuously performed, so able to fix and decrease undernutrition incidence among toddlers.

\section{References}

1. World Health Organization. Method and development: interpretation guide. Geneva: World Health Organization; 2005.

2. Fatmah. Pengetahuan dan praktek keluarga sadar gizi ibu balita. Kesmas: Jurnal kesehatan Masyarakat Nasional. 2010; 4 (4): 162 - 71.

3. Hartanto RD, Nasrin K. Pengaruh status gizi anak usia di bawah lima tahun terhadap nilai belajar verbal dan numerik. Kesmas: Jurnal Kesehatan Masyarakat Nasional. 2009; 3 (4): 177 - 84.

4. Badan Penelitian dan Pengembangan Kesehatan Kemeterian Kesehatan Republik Indonesia. Laporan riset kesehatan dasar (Riskesdas) 2013. Jakarta: Balitbangkes Kemeterian Kesehatan Republik Indonesia; 2013.

5. Dinas kesehatan Kota Tangerang. Profil dinas kesehatan Kota Tangerang tahun 2013. Tangerang: Dinas Kesehatan Kota Tangerang; 2013.

6. Kuntari T, Nur AJ, Sunarto, Kurniati. Faktor risiko malnutrisi pada balita. Kesmas: Jurnal Kesehatan Masyarakat Nasional. 2013; 7 (12): 5726.

7. Rahmadini N, Trini S, Diah M. Status gizi balita berdasarkan composite index of anthropometric failure. Kesmas: Jurnal Kesehatan Masyarakat Nasional. 2013; 7 (12): 538 - 44.

8. Huriah T, Laksono T, Fitri H, Madarina J. Malnutrisi akut berat dan determinannya pada balita di wilayah rural dan urban. Kesmas: Jurnal Kesehatan Masyarakat Nasional. 2014; 9 (1): 50 - 7.

9. Departemen Kesehatan Republik Indonesia. Pedoman nasional penanggulangan rencana aksi nasional pencegahan dan penanggulangan gizi buruk. Jakarta: Departemen Kesehatan Republik Indonesia; 2006.

10. Ogunba B. Maternal behavioural feeding, practices and underfive nutrition implication for child development and care. Journal of Applied Sciences Research. 2006; 2 (12): 1132 - 6.

11. Kartono D, Amelia, Anies I. Keadaan gizi anak balita di wilayah Bogor, Tangerang dan Bekasi selama krisis ekonomi. Buletin Penelitian Kesehatan. 2002; 30 (1): 1-10.

12. Lubis R. Hubungan pola asuh ibu dengan status gizi anak balita di wilayah kerja Puskesmas Pantai Cermin Kecamatan Tanjung Pura Kabupaten Langkat [bachelor thesis]. Medan: Fakultas Kesehatan Masyarakat Universitas Sumatera Utara; 2008.

13. Bullen P. The positive deviance/hearth approach to reducing child malnutrition: systemic review. Tropical Medicine and International Health. 2011; 16 (11): 1354 - 66.

14. Sartika RAD. Analisis pemanfaatan program pelayanan kesehatan status gizi balita. Kesmas: Jurnal Kesehatan Masyarakat Nasional. 2010; 5 (2): 
$76-83$.

15. Kumar D, Goel NK, Mittal PC, Misra P. Influence of infant feeding practice on nutritional status of underfive children. Indian Journal of Pediatrics. 2006; 73 (5): 417 - 22.

16. Ramji S. Impact of infanct and young child feeding and caring practices on nutritional status and health. Indian Journal of Medical Research. 2009 Nov; 130 (5): 624 - 6.

17. Hidayat TS, Abas BJ. Perilaku pemanfaatan posyandu: hubungannya dengan status gizi dan morbiditas balita. Buletin Penelitian Kesehatan. 2012; 40 (1): 1 - 10. 